\title{
Management of Slum Settlements based on Sustainable Development in the Deli Watershed of Medan City
}

\author{
Adang Aldhila ${ }^{1}$, Hardi Warsono ${ }^{2}$, Sri Suwitri ${ }^{3}$, Retno Sunu Astuti ${ }^{4}$ \\ 1,2,3,4 Public Administration Study Program, Faculty of Social and Political Sciences, Universitas Diponegoro \\ Indonesia \\ adangaldhila@gmail.com
}

\begin{abstract}
The population in urban areas continues to increase while the land owned is limited which results in slum settlements in urban areas. Slum settlements in Medan City often appear in areas where buildings should not be allowed, such as in watersheds. Deli River as a large river that divides Medan City, there are still many slum settlements in the watershed. Management of slum settlements based on sustainable development is needed to provide a long-term impact, especially for the preservation and restoration of the function of the Deli River. This study aims to analyze the management of slum settlements based on sustainable development indicators in achieving sustainable development, namely ecological sustainability, economic sustainability, socio-cultural sustainability, political sustainability, and defense and security sustainability. The research method used is descriptive qualitative. Sources of research data by collecting primary data through interviews and secondary data through documentation and observation studies. The management of slum settlements based on sustainable development in the Deli watershed is still not optimal in terms of ecological sustainability, economic sustainability, and defense and security sustainability. Meanwhile, socio-cultural sustainability and political sustainability are quite optimal. The government must manage slum settlements based on sustainable development through an approach with the community and provide viable housing alternatives so that people do not live in watershed areas.
\end{abstract}

Keywords

management; slum settlements, watershed, sustainable development

\section{Introduction}

Population growth has so far been a difficult problem for the government to solve. The problem of continuing to increase population growth rates is often found in big cities as a result of urbanization. Rural communities are forced to venture into urban areas with the hope of improving their quality of life. Population growth which is difficult to control and limited land area has resulted in a continuing increase in population density. Population density is a serious problem that is difficult to solve in big cities like Medan.

Medan City is the third largest city category in Indonesia after Jakarta and Surabaya and also as the first largest city outside Java Island. The city of Medan is the capital of North Sumatra Province, which is the center of the economy and one of the areas where people are urbanizing. Medan City has an area of $265.10 \mathrm{~km} 2$ with a population of 2,435,252 people. The population growth rate in Medan City from 2010 to 2020 was $1.45 \%$, which resulted in the population density in Medan continuing to increase. In 2010 the population density of Medan City was 7,912.52 per km2 and then increased in 2020 to 9,186.16 per km2 (BPS Kota Medan, 2021). 
The rapid rate of population growth and limited land in the city of Medan has created slum settlements in the city of Medan. The impact of high population growth is the increasing need for natural resources, especially land (Nandi, 2011). The residents must fight for the house as a basic need. The large number of residents in the city also requires a lot of land needed to build a place to live. People who do not have the ability to buy land will build houses in areas that are not feasible or even violate the rules, resulting in slum settlements.

The term slum settlement has been regulated in "Law Number 1 of 2011 concerning Housing and Settlement Areas which states that slum settlements are uninhabitable settlements due to building irregularities, high levels of building density, and insufficient quality of buildings and facilities and infrastructure. terms ". Slum settlements often appear in areas where buildings should not be allowed, such as in watersheds (DAS). Slum settlements in the watershed can damage the face of the city, more fatally it can cause flooding.

Medan City has a large part of the area that is located in the lowlands and is the meeting place of the large rivers that divide the city, namely the Deli River and the Babura River, making Medan a flood-prone area. In 2020, there were 32 floods hitting Medan City (BPBD Medan City, 2021). Floods in Medan City generally occur due to the reduced capacity of the river to accommodate large water discharges and the frequent finding of a lot of garbage that interferes with the river's performance in flowing water causing the river to overflow (Ramadhan and Matondang, 2016). The urban areas most prone to flooding are of course the settlements in the watershed area. The last flood in Medan City at the end of 2020 occurred due to the overflow of the Deli River and resulted in the settlement in the Deli River watershed being flooded (Tribun Medan, 2020).

The slum settlement in the Deli River watershed is one of the factors that resulted in the overflow of the Deli River. The Deli River overflow occurred due to the presence of a lot of garbage and the narrowing of the river to drain the water. Flooding due to the overflowing of the Deli River has an impact on welfare and is even dangerous for the community in the settlements along the Deli River. This problem certainly needs a touch by the local government in its resolution. Through the Housing, Zone, Settlement and Spatial Planning Agency (PKPPR) Medan City, which is responsible for spatial planning for Medan City, including slum settlements in the Deli River watershed, it is hoped that they will be able to manage these slums by applying the principles of sustainable development.

Management of slum settlements based on sustainable development in the watershed of the Deli River, Medan City is very much needed to overcome this problem. The settlement of slum settlements in urban areas must be based on the principles of sustainable development (Ervianto and Felasari, 2019). Sustainable development-based management will be able to provide long-term impacts, not only temporarily. Arikunto (1993) The word "management" means the same as management which means arrangement or management. Terry (2009) argues that "management is the same as management so that management can be understood as a differentiating process of planning, organizing, mobilizing and controlling". Robbins and Coulter (2012),

Sustainable development (Sustainable Development) is a concept to carry out development by considering long-term impacts without sacrificing the fulfillment of resource needs for future generations. The origin of the emergence of the concept of sustainable development stems from concern for the environment. Budiharjo and Sujarto (2009) "Sustainable development is a city which in its development is able to meet the needs of today's society, is able to compete in the global economy by maintaining the 
beauty of its social, cultural, political, and defense and security environment without neglecting or reducing the ability of future generations to meet their needs". Furthermore, Djajadiningrat (2005) suggests indicators in achieving sustainable development, namely "ecological sustainability, economic sustainability, socio-cultural sustainability, political sustainability, and defense and security sustainability". The experts have poured many ideas related to development which are expected to achieve the balance of nature and human needs. Various environmental ethics have become studies that are often voiced in efforts to preserve environmental ecology (Pandapotan and Silalahi, 2019). Management of slum settlements based on sustainable development in the watershed of the Deli, Medan City, is analyzed by looking at the management carried out by the government. The management that is carried out must meet the indicators in achieving sustainable development.

\section{Research Methods}

The research method was designed as a descriptive study and used a qualitative approach. Descriptive method is a method to describe or describe a phenomenon that is being researched. Sugiyono (2018) defines a qualitative approach based on the philosophy of postpositivism, which aims to research phenomena scientifically, making the researcher himself a key instrument and the results prioritizing the meaning of research rather than generalization. Research with a qualitative approach can find real data to hidden data that can be observed.

Sources of data in research are obtained through primary data collection and secondary data that can help analyze. Primary data collection was carried out through interviews with employees at the PKPPR Office of Medan City who are responsible for and know about the management of slum settlements in Medan City, as well as people who live in slums in the Deli River basin, Medan City. Secondary data obtained through documentation and observation.

\section{Results And Discussion}

\subsection{Slum Settlements in the Deli River Basin, Medan City}

Slum settlements can be viewed from the 7 indicators stipulated in "Regulation of the Minister of Public Works and Public Housing Number 2 of 2018 concerning Prevention and Quality Improvement of Slum Housing and Slum Settlements". Indicators that must be considered in determining slum areas include buildings, environmental roads, environmental drainage, drinking water supply, solid waste management, waste water management, and fire protection. Slum settlements can be divided into two types, namely slum and squatter. Slum is a slum area located in a legal area, while squatter is a slum which is not in a housing zone or can be said to be illegal. A river basin is an area that is prohibited from constructing buildings, one of which is because it has the potential to disrupt river performance so that the impact can cause flooding. The prohibition to build buildings in river basins is contained in "Government Regulation Number 38 of 2011 concerning Rivers". Slum settlements in the watershed area are still widely scattered in Medan City, one of which is the slum settlements located in the Deli River basin, Medan City.

Slum settlements located in the watershed area of the Deli River, Medan City, occur because there is no longer any land or even legal slums to accommodate the increasing population, resulting in the formation of slum settlements in illegal areas. The high price of 
land in the city center makes residents unable to buy land and is forced to build houses in the watershed of the Deli River. Slum settlements in the watershed of the Deli River, Medan City, can be determined the level of slum based on 7 indicators of slum and slum settlements. The determination of the level of slum in the Deli River watershed was carried out by a team from the Kota Tanpa Kumuh (KOTAKU), which is a national program to address slums in the city.

Table 1. Distribution of Slum Settlements in the Deli Watershed (DAS) in 2020

\begin{tabular}{|c|c|c|c|c|c|c|c|}
\hline \multirow{2}{*}{$\begin{array}{c}\text { Sub- } \\
\text { district }\end{array}$} & \multirow[b]{2}{*}{ Environment } & \multicolumn{2}{|c|}{ Population } & \multicolumn{2}{|c|}{ Large } & \multicolumn{2}{|c|}{ Slum } \\
\hline & & Amount & Density & $\begin{array}{l}\text { Settlement } \\
\text { (Ha) }\end{array}$ & $\begin{array}{c}\text { Grungy } \\
\text { (Ha) }\end{array}$ & Score & Level \\
\hline \multirow{2}{*}{$\begin{array}{l}\text { Gedung } \\
\text { Johor }\end{array}$} & 002 & 1605 & Moderate & 9,35 & 7,86 & 19 & Light Slum \\
\hline & 006 & 881 & Moderate & 21,69 & 20,76 & 19 & Light Slum \\
\hline \multirow{4}{*}{$\begin{array}{c}\text { Titi } \\
\text { Kuning }\end{array}$} & 002 & 2606 & High & 10,95 & 6,75 & 21 & Light Slum \\
\hline & 005 & 1249 & High & 8,93 & 2,09 & 21 & Light Slum \\
\hline & 011 & 2632 & High & 18,72 & 6,03 & 20 & Light Slum \\
\hline & 015 & 1688 & High & 15,98 & 7,40 & 27 & Light Slum \\
\hline \multirow{3}{*}{$\begin{array}{l}\text { Kedai } \\
\text { Durian }\end{array}$} & 002 & 2161 & High & 2,57 & 1,81 & 23 & Light Slum \\
\hline & 004 & 4505 & High & 10,21 & 4,78 & 21 & Light Slum \\
\hline & 005 & 1428 & High & 7,89 & 7,04 & 24 & Light Slum \\
\hline \multirow{3}{*}{$\begin{array}{c}\text { Belawan } \\
\text { Bahari }\end{array}$} & 004 & 844 & Moderate & 3,59 & 3,59 & 28 & Light Slum \\
\hline & 005 & 816 & Moderate & 8,02 & 8,02 & 21 & Light Slum \\
\hline & 005 & 637 & Moderate & 1,54 & 1,54 & 26 & Light Slum \\
\hline \multirow{8}{*}{$\begin{array}{c}\text { Pekan } \\
\text { Labuhan }\end{array}$} & 005 & 224 & Moderate & 1,81 & 1,81 & 27 & Light Slum \\
\hline & 006 & 371 & Moderate & 1,12 & 1,12 & 34 & Light Slum \\
\hline & 009 & 550 & Moderate & 4,10 & 3,55 & 25 & Light Slum \\
\hline & 010 & 646 & Moderate & 3,33 & 3,33 & 19 & Light Slum \\
\hline & 012 & 647 & Moderate & 3,10 & 3,10 & 27 & Light Slum \\
\hline & 025 & 940 & Moderate & 6,18 & 6,18 & 25 & Light Slum \\
\hline & 025 & 892 & Moderate & 3,08 & 3,08 & 33 & Light Slum \\
\hline & 027 & 735 & Moderate & 2,70 & 2,70 & 16 & Light Slum \\
\hline \multirow{10}{*}{$\begin{array}{l}\text { Belawan } \\
\text { Bahagia }\end{array}$} & 002 & 377 & Moderate & 6,79 & 6,79 & 21 & Light Slum \\
\hline & 003 & 760 & Moderate & 1,33 & 1,33 & 26 & Light Slum \\
\hline & 004 & 402 & Moderate & 1,27 & 1,27 & 41 & Medium Slum \\
\hline & 005 & 432 & Moderate & 1,19 & 1,19 & 24 & Light Slum \\
\hline & 006 & 306 & Moderate & 1,07 & 1,07 & 29 & Light Slum \\
\hline & 007 & 292 & Moderate & 2,20 & 2,20 & 35 & Light Slum \\
\hline & 010 & 526 & High & 1,38 & 1,38 & 31 & Light Slum \\
\hline & 011 & 312 & High & 1,75 & 1,75 & 25 & Light Slum \\
\hline & 013 & 592 & High & 2,07 & 2,07 & 22 & Light Slum \\
\hline & 017 & 735 & High & 2,15 & 2,15 & 22 & Light Slum \\
\hline \multirow{5}{*}{$\begin{array}{c}\text { Bagan } \\
\text { Deli }\end{array}$} & 001 & 858 & High & 3,47 & 3,47 & 21 & Light Slum \\
\hline & 002 & 749 & High & 3,33 & 3,33 & 18 & Light Slum \\
\hline & 005 & 1811 & Moderate & 1,91 & 1,91 & 38 & Medium Slum \\
\hline & 006 & 857 & High & 2,26 & 2,26 & 23 & Light Slum \\
\hline & 015 & 1458 & Moderate & 4,65 & 4,65 & 31 & Light Slum \\
\hline \multirow{2}{*}{ Aur } & 003 & 1340 & High & 14,10 & 11,49 & 23 & Light Slum \\
\hline & 004 & 1236 & High & 9,88 & 7,71 & 27 & Light Slum \\
\hline \multicolumn{4}{|c|}{ TOTAL } & 205,66 & 158,56 & $\begin{array}{c}25,2 \\
\text { (Average) }\end{array}$ & Light Slum \\
\hline
\end{tabular}

Source: Medan City Coordinator, Kotaku Program

Determination of the level of slum in an area has been regulated in "Regulation of the Minister of Public Works and Public Housing Number 2 of 2018 concerning Prevention and Quality Improvement of Slum Housing and Slum Settlements" which is 
divided into certain levels. The first level of slum is mild slum if it gets a value of 16-37. The second level of slum is moderate slum if it gets a score of 38-59. The third level of slum is heavy slum if it gets a value of 60-80. The slum settlements that are scattered in the watershed area of the Deli River, Medan City are 158.56 hectares with an average slum value of 25.2 which means they are in the mild slum category. The title of mild slum is not an excuse for not managing slum settlements in the Deli River area of Medan City, considering that these slums are located in an illegal and dangerous area. Management of slum settlements in the Deli River watershed must be carried out by applying the principles of sustainable development so that the management carried out can have long-term impacts.

\subsection{Management of Slum Settlements Based on Sustainable Development in the Deli River Basin, Medan City}

Slum housing in the watershed of the Deli River, Medan City, is very complex in terms of its management. Management must pay attention to the environment, economy and society at the same time without neglecting any of these important aspects. Management based on sustainable development (sustainable development) is a development that will have a long-term impact than conventional development. It is hoped that the management of slum settlements based on sustainable development is the answer to this problem. Management of slum settlements based on sustainable development in the watershed of the Deli River, Medan City, must pay attention to indicators to achieve sustainable development. According to Ridwan et al (2020), Cological citizenship is a new idea that is strived to shape the awareness of citizens in forming a whole human being in the involvement of protecting the environment. Djajadiningrat (2005) suggests indicators in achieving sustainable development, namely "Ecological sustainability, economic sustainability, socio-cultural sustainability, political sustainability, and defense and security sustainability".

\section{a. Ecological Sustainability}

Ecological sustainability in the management of slum settlements based on sustainable development can be seen from the efforts to restore the function of rivers and environmental sustainability in the Deli River basin, Medan City. Since 2010 the local government has planned to carry out normalization on the banks of the Deli River, however, due to the presence of slum settlements in the Deli River watershed it has resulted in difficulties in realizing the normalization of the Deli River. Another effort made by the local government through the PKPPR Office of Medan City invites people in slum settlements in the Deli River watershed to preserve the river by not littering, especially in the Deli River (Results of interview, 2021).

Another obstacle in managing ecological sustainability is that there is still a lot of waste in the Deli River watershed. The Child Care Community Foundation and the Deli River (Kopasude) found 74 points of dumping garbage that had been mounting along the Deli River. Not stopping at garbage, Kopasude also found a point as a disposal site for factory waste to the Deli River (Merdeka.com, 2021). Slum settlement buildings that eat up the riverbanks cause the narrowing of the river area and the existing garbage causes sedimentation in the Deli River so that the Deli River experiences silting. The narrowing and silting of the Deli River may result in a reduction in the river's ability to accommodate water discharge. When high rainfall causes river water to overflow so that it inundates slum settlements in the Deli River watershed. 
Based on this, it can be said that the management of slum settlements in the Deli River Basin is still not optimal when viewed from ecological sustainability. Ecological sustainability is one very important indicator in the concept of sustainable development. Moreover, sustainable development is born out of concern for the environment.

\section{b. Economic Sustainability}

Economic sustainability in the management of sustainable development-based slum settlements in the Deli River Basin, Medan City can be seen through economic efficiency, economic prosperity, and increased distribution distribution and prosperity. Relocation of residents' residences is an effort to sustain the economy. The local government through the PKPPR Office of Medan City provides alternative housing in the form of 2 flats located in Medan Labuhan District and Medan Deli District. The PKPPR Office has also set prices based on the relatively cheap "Medan Mayor Regulation No. 29/2013 on Rental Rates for Simple Flats", starting from Rp. 73.300 to Rp. 230.000,-. However, with this price, there are still many people who refuse and choose to stay on land that cannot even have a land title.

The constraints faced in relocating the slum settlements on the banks of the Deli River, namely originating from the community itself. The main reason is because people feel that they have been passed down from generation to generation and are comfortable living on the banks of the Deli River. Furthermore, people also tend to refuse to be relocated to existing flats, because most of the community are informal workers whose apartment is inefficient distance to the center of the city where they are looking for income. For people who are old enough, it is also an obstacle, because it will make it difficult for them in the apartment which requires them to climb stairs.

Economic sustainability in the management of slum settlements in the Deli watershed still needs to be considered properly. The existing flats must be fully used so that there are no more people living in slum settlements. Living in a legal housing area can improve the welfare of the community because they have the right to their place of residence. Meanwhile, living in an illegal area means that at any time you can be forcibly evicted.

\section{c. Socio-Cultural Sustainability}

The socio-cultural sustainability in the management of slum settlements based on sustainable development in the Deli River basin in Medan City can be seen through population stability, meeting basic human needs, and maintaining cultural diversity. The local government's efforts in socio-cultural sustainability through a national program, namely Cities Without Slum (KOTAKU) create social institutions consisting of residents of the slum areas themselves who run this community organization. The Community SelfHelp Organization (LKM) is a community organization formed within the scope of the kelurahan and is useful as a bridge between the slum community and the government.

The PKPPR Office of Medan City as the leader of the City Without Slum Program (KOTAKU) empowers the community through Community Self-Reliance Institutions (LKM) in the Deli River watershed. Community empowerment is carried out by understanding the MFI about 7 indicators of slum settlements and regulations regarding the prohibition of building buildings in river basins. Furthermore, the LKM functions to invite other communities to jointly manage the slum settlements and the watershed of the Deli River. MFIs that contain local residents can certainly build good social relationships with other communities and create a good culture such as a culture of mutual cooperation. 
The socio-cultural sustainability in the management of slum settlements in the watershed of the Deli River, Medan City is quite optimal. LKM as a social organization which is an extension of the government is expected to be able to solve problems or problems in the socio-cultural aspects related to slum settlements. The social problem in question is about how the community can care about the environment, one of which is by reprimanding people who still do not throw garbage in their place.

\section{d. Political Sustainability}

Political sustainability in the management of slum settlements based on sustainable development in the Deli River basin, Medan City can be seen through community involvement and paying attention to a transparent and responsible democratic process. The PKPPR Office's efforts in political sustainability are imposing direct elections for the management of LKM in each slum settlement village. Management elections can only be nominated by residents of the kelurahan and cannot nominate themselves. The management of the LKM does not have a chairman, only has an odd number of commissioners to facilitate the deliberation process.

The elected LKM management is fully responsible for the management of the slum settlements in the village. LKM has the right to express opinions about the needs of its subdistrict at the village level musrembang. The results of the musrembang will be used as input for local governments to become program priorities. The aim of implementing this is so that the policy is bottom-up. Bottom-up policies can match the needs of the lowest level, but still do not violate regulations from the center. Thus, political sustainability in the management of slum settlements in the watershed of the Deli River, Medan City is quite good.

\section{e. Defense and Security Sustainability}

The sustainability of defense and security in the management of slum settlements based on sustainable development in the Deli River basin in Medan City can be seen through how to overcome external and internal threats that endanger the community. Efforts to overcome threats that endanger the community are carried out by the Regional Disaster Management Agency (BPBD) and the local police. BPBD's efforts in overcoming the threat of disaster to the community through cooperation between provincial and city BPBDs and various other parties such as ACT and Dompet Dhuafa through river cleaning activities to reduce the risk of flooding in Medan City (BPBD.sumutprov, 2020).

The police's efforts in dealing with defense and security are by continuing to provide services related to the prevention of crimes that can endanger people in slum areas. Apart from the police, the community in the slum areas of the Deli River watershed also maintains the security of their environment by setting up security posts and scheduling night patrols (Results of interview, 2021). Protection from the surrounding community is expected to be able to make the area safe from criminal acts such as theft, fights, and other actions that disturb the community.

The obstacle that is difficult to deal with in overcoming the threat in the slum settlements in the area of the Deli River is the flood disaster. The last flood in Medan was due to the overflow of the Deli River which caused 2,773 houses to be submerged. While the affected residents were 1,983 families and 5,965 people (iNewsSumut.id, 2020). Although the BPBD, police, and the community have made defense and security efforts, the threat of flooding is unavoidable for residents of the slum settlements in the Deli River basin, Medan City. 
The sustainability of defense and security in slum management is not optimal. The government has made efforts to overcome threats from outside and from within by involving various stakeholders. The security of the community in the slum settlements in the watershed of the Deli River is still worrying because it is prone to flooding. This could endanger the safety of the community in the Deli River basin, Medan City.

\section{Conclusion}

The area of the slum settlements in the watershed of the Deli River, Medan City reaches 158.56 hectares and is included in the category of slum settlements with low slum levels. Even though it is included in the low level of slum, the slum settlement in the Deli River watershed needs to be managed properly because the slum settlements are located in an illegal area. Management of slum settlements in watersheds must be based on the principle of sustainable development. Management of slum settlements based on sustainable development in the watershed of the Deli River, Medan City, seen from the indicators of ecological sustainability, economic sustainability, and sustainability of defense and security are still not optimal. However, the indicators of socio-cultural and political sustainability are optimal in the management of slum areas based on sustainable development. Local governments must manage slum settlements based on sustainable development through approaches with the community and provide alternative housing that is feasible so that people do not live in the watershed. One alternative is to build flats not far from their initial residence.

\section{References}

Arikunto, Suharsimi. (1993). Manajemen Penelitian. Jakarta: PT Raja Grafindo Persada. BPBD Sumut. (2020, 18 Februari). Mitigasi Bencana Banjir BPBD Provsu Gelar Kegiatan Bersih Sungai Deli. Diakses pada 9 April 2021, dari https://bpbd.sumutprov.go.id/mitigasi-bencana-banjir-bpbd-provsu-gelar-kegiatanbersih-sungai-deli/2020/.

BPS Kota Medan. (2021, 26 Februari). Kota Medan Dalam Angka 2021. Diakses pada 24 Maret 2021 ,

dari https://medankota.bps.go.id/publication/2021/02/26/695922e9701d335f2207cf74/kot a-medan-dalam-angka-2021.html.

Budiharjo, Eko. \& Sujarto, Djoko. (2009). Kota Berkelanjutan (Sustainable City). Bandung: PT Alumni.

Djajadiningrat, S.T. (2005). Sustainable Future: Menggagas Warisan Peradaban bagi Anak Cucu, Indonesia. Jakarta: Center of Sustainable Development.

Ervianto, Wulfram I. \& Felasari, Sushardjanti. (2019). Pengelolaan Permukiman Kumuh Berkelanjutan di Perkotaan. Jurnal Spektran, 7(2), 178-186.

iNewsSumut.id. (2020, 5 Desember). Sungai Deli Medan Meluap Lagi, Ratusan Rumah Terendam Banjir. Diakses pada 9 April 2021, dari https://sumut.inews.id/berita/sungai-deli-medan-meluap-lagi-ratusan-rumahterendam-banjir.

Merdeka.com. (2021, 31 Maret). 74 Gunung Sampah Ditemukan di Bantaran Sungai Deli Medan. Diakses pada 9 April 2021, dari https://www.merdeka.com/peristiwa/74gunung-sampah-ditemukan-di-bantaran-sungai-deli-medan.html.

Nandi. (2011). Promoting Sustainable Development in Spatial Planning of Bandung City. International Conference on the Future of Urban and Peri-Urban Area, 280-288. 
Pandapotan, S., Silalahi. H. (2019). Social Capital as a Local Wisdom of Farmer in Managing Agricultural Resources in Lubuk Pakam Sub-district, Deli Serdang District. Budapest International Research and Critics Institute-Journal (BIRCIJournal) Vol 2, No 4, Page: 469-476.

Peraturan Menteri Pekerjaan Umum dan Perumahan Rakyat Nomor 2 Tahun 2018 Tentang Pencegahan dan Peningkatan Kualitas Terhadap Perumahan Kumuh dan Permukiman Kumuh.

Peraturan Pemerintah Nomor 38 Tahun 2011 Tentang Sungai.

Peraturan Wali Kota Medan Nomor 29 Tahun 2013 Tentang Tarif Sewa Rumah Susun Sederhana.

Ramadhan, Ilham. \& Matondang, Armansyah. (2016). Peran Badan Penanggulangan Bencana Daerah Kota Medan dalam Penanggulangan Bencana Alam. Jurnal Ilmu Pemerintahan dan Sosial Politik UMA, 4(2), 176-185.

Ridwan, F. T., et al. (2020). Strategy for Development of Ecological Citizens by Walhi Yogyakarta through Community-Based Education in Communities Gunung Sewu. Budapest International Research and Critics Institute-Journal (BIRCI-Journal) Vol 3, No 2, Page: 1095-1104

Robbins, Stephen P. \& Coulter, Mary. (2012). Management, Eleventh Edition. United State of America: Pearson Education Limited.

Sugiyono. (2018). Metode Penelitian Kuantitaif, Kualitatif dan R\&D. Bandung: Alfabeta.

Terry, George R. (2009). Prinsip-prinsip Manajemen. Jakarta: Bumi Aksara.

Tribun-Medan.com. (2020, 3 Desember). Sungai Deli Kembali Meluap, Warga Terpaksa Mengungsi, Lukman: Ini Banjir Terbesar Sepanjang Tahun. Diakses pada 24 Maret 2021, dari https://medan.tribunnews.com/2020/12/03/sungai-deli-kembali-meluapwarga-terpaksa-mengungsi-lukman-ini-banjirterbesar-sepanjang-tahun.

Undang-Undang Nomor 1 Tahun 2011 Tentang Perumahan dan Kawasan Permukiman. 